and irrigation the external wound was pared and carefully sutured, when the usual aseptic dressings were applied.

The second patient, was a boy ten years old with the following history: Six months previously he had scarlet fever, after which he suffered from nephritis, and rheumatic pains in the lower limbs. About three months ago, two suppurative points broke out on the inner surface of the left leg, from which a sero-purulent matter has since issued. After awhile along the same plane, and on the same surface, many other purulent foci erupted, and now as can be seen, one side of the limb, from the knee downward, is covered with port-holes which communicate with necrosed bone. Twice the pus has made its way to the surface. All severe pain in the limb has ceased.

What is the pathological character of the process which has led to such extensive bone disease? Is the lesion tubercular? In answer to this one might ask, is the specific germ present? We niay say, that it has not been proved. In fact, I attach no importance whatever, to the presence or absence of this germ, for it is incontestibly true that we may, and do have strumous disease, so-called tuberculosis without the bacillus. And, again we often find myriads of them, in the laudable pus of a healthy strumous wound. The fact is, that the basis of this boy's disease is blood change. The poison of scarlet fever is terribly destructive to the blood, and the vasomotor nerves. In this case, the deeper layers of bone, lining the medullary canal have simply perished, through mal-nutrition. It may be noted that although there is extensive disease of this boy's leg, yet he walks without a limp. This is commonly found in all cases, where the bone lesion is at a considerable distance from an articulation.

On an examination of the limb, I find a probe will enter any one of those apertures and penetrate deeply into the medullary cavity. Small, loose particles of sequestra can be felt at the top of the probe. Now, I will by surgical interference endeavor, at least, to do to this boy no harm; that is, I will simply enlarge those openings and endeavor to pick out with the dressing forceps, the fragments of remaining dead bone, which the natural processes of life are, unaided, rapidly disintegrating and throwing off, by liquifaction. It might be said that as I have not very extensively opened the cavity of this bone some microscopical foci of the disease may have remained. But, in my experience the generalization of tubercle is never dependent on a local lesion; hence, I am confident that in operating in these cases, it is better to err on the side of conservatism, than to take chances on an extensive mutilation and consequent damage to structures, which might have been preserved, if nothing whatever had been done, other than by a tentative therapy.

\section{PRACTICE OF MEDICINE IN ANCIENT ROME.}

\section{BY J. F. JENKINS, M.D.,} OF TECUMSEH, Mich.

In an early day, the practice of medicine in Rome was chiefly confined to foreigners, principally Greeks. Most of the physicians whose names are handed down to us are of Greek origin, yet there were many Egyptians and Syrians, who practiced medicine in Rome as well as in the provincial cities. If we go still further back in the history of Rome, first century. we find wealthy families who kept many slaves, and would have one of their number skilled in the medical art, who would gratuitously practice for the household but received compensation from those outside of the household.

During the reign of the Cæsar's, and the century following many physicians in Rome became very popular; some of them received large fees which would compare very favorably with the fees of the popular physicians of the present day.

Pliny the Elder states that an ex-praetor, who had leprosy paid a physician 20,000 sesterces, about $\$ 8$,000 , but he does not state how long he attended him, whether it was for one visit or for several of them. The same author states that there were five physicians in his day whose annual income amounted to 250,000 sesterces, equal to $\$ 10,000$ per annum. The physician to the emperor Claudius, Stertinius by name, received 500,000 sesterces, or $\$ 20,000$ per annum, still he claimed he could make in private practice 600 ,000 sesterces or $\$ 24,000$ yearly. The amount which this physician received from Claudius is probably equal if not greater than the salary of any modern court physician.

Stertinius and his brother who was also a physician, left a fortune of thirty millions of sesterces, or one million two hundred thousand dollars, besides making large donations during their lifetime to the city of Naples. Pliny mentions another physician, named Cranus of Marsailles, who gave largely, and spent money very freely, yet, notwithstanding his extravagant life, left a fortune of ten million sesterces, a sum equal to four hundred thousand dollars.

In the Roman empire, there was no law regulating the practice of medicine consequently many, as in our day commenced the practice of medicine with little or no preparatory education; many left trades and other occupations, and with a large supply of effrontry commenced the practice of the healing art. I,ike their modern type, some succeeded while others failed.

During the first century of the Christian era, there had developed all sorts of specialists; there were surgeons, gynecologists, oculists, aurists, dentists, etc., in all probability as great a variety as the nineteenth century has developed-in this way we find history repeating itself. Different schools of medicine existed, among which may be mentioned the "wine-givers" who no doubt were very popular in their day; the cold water doctors, one of whom named Antonius Musa gained the reputation of saving the life of the first Roman emperor, Augustus, although it is said that he killed Marcellus.

Pliny makes a statement that we very often hear at the present day, that physicians frequently try experiments upon their patients, and that the doctor is the only man in the community who may kill people without punishment.

Doubtless medical knowledge had made some progress since the days when Hippocrates taught the healing art under that famous old tree in the Isle of Cos, but our means of knowing how much progress was made is very limited, yet when I looked over the house of the surgeon in Pompeii, and examined the instruments that were taken out of this house, (which are in the museum at Naples), I am led to believe that the educated physician and surgeon of that day was in every way equal to the civilized society of the 